\title{
THE PURSUE OF THE CUSTOMER LOYALTY: STUDY ON CONSUMER OVO DIGITAL- WALLET USERS IN JAKARTA
}

Eddy John, Yudi Yulius and Wilhelmus Hary Susilo*

University of Persada Indonesia YAI

DOI: http://dx.doi.org/10.38193/IJRCMS.2021.3301

\begin{abstract}
The purpose of this study was to determine the effect of intellectual capital, digital technology quality, and customer knowledge on value creation and its implications for customer loyalty on OVO digital wallet users in Jakarta partially and together. Furthermore, the 255 sample of this study is consumers who use OVO digital wallets. In this study in Jakarta- Indonesia and the data analysis method conducted within the Structural Equation Modeling and the confirmed strategic analysis. Hence, the results showed:1) Intellectual capital has a partial effect on value creation in consumers who use OVO digital wallets; 2) Digital technology quality partially influences value creation in consumers who use OVO digital wallets; 3) Customer knowledge partially influences value creation in consumers who use OVO digital wallets; 4) Intellectual capital, digital technology quality and customer knowledge simultaneously influence the value creation of OVO digital wallet users; 5) Intellectual capital affects customer loyalty to consumers who use OVO digital wallets; 6) Digital quality technology has a partial effect on customer loyalty to consumers who use OVO digital wallets; 7) Customer knowledge affects customer loyalty to consumers who use OVO digital wallets; 8) Value creation affects customer loyalty to consumers who use OVO digital wallets; 9) Intellectual capital, digital technology quality, customer knowledge and value creation together have a simultaneous effect on customer loyalty of OVO digital wallet users with R square value .85, so that the results of this study found the results of intellectual capital, digital technology-quality, and customer knowledge influence customer loyalty through variable value creation had the full mediation research marketing model.
\end{abstract}

KEYWORDS: Intellectual Capital, Digital Technology Quality, Customer Knowledge, Value Creation, Customer Loyalty

\section{INTRODUCTION}

The business with the market- based management in marketing science that should in the globalpandemic situations within an emerging market, need more the marketer- skill, effort, direction, persistence and the task marketing strategies within the digital-marketing, salesperson experiences and the integration marketing- team as the research gaps from the previous research that could leads to the distinctive marketing- performance and customers value co- creation and an implication on customer loyalty, that it not to be confirm result of the research on the digital- wallet within the fin- 
ISSN 2582-2292

Vol. 3, No. 03 May-June; 2021

tech recently in among firms. (Fu, 2009; Harrigan, Evers, Miles, \& Daly, 2017; Xu, Wang, \& Wen, 2019), (Bitter \& Grabner-Kräuter, 2016; Chang, Jiang, Klein, \& Wang, 2019; Day, Crown, \& Ivany, 2017)

Moreover, the business gap within the level of the customer loyalty to utilize the digital- wallet in Jakarta, could be provide and indicated the fluctuated condition and could describe on entire situations, as show table 1, below:

Table 1. Customer Loyalty (CL)

\begin{tabular}{|c|l|c|c|c|c|c|}
\hline No & \multicolumn{1}{|c|}{ Statement } & N & Min & Max & Mean & Std. Dev \\
\hline CL1 & Recommended & 255 & 1 & 5 & 4,25 & 1,26 \\
\hline CL2 & Well- services & 255 & 1 & 5 & 4,25 & 1,28 \\
\hline CL3 & Good performance & 255 & 1 & 5 & 4,28 & 1,26 \\
\hline CL4 & Applied the fin-tech & 255 & 1 & 5 & 4,31 & 1,26 \\
\hline CL5 & The first choice & 255 & 1 & 5 & 4,29 & 1,27 \\
\hline CL6 & The high- Intention & 255 & 1 & 5 & 4,23 & 1,25 \\
\hline & Mean & \multicolumn{5}{|c|}{} \\
\hline
\end{tabular}

Source: the prime- data, 2020

Nevertheless, in global- pandemic have the decreased, more challenging, and need the wellmanagement, while empirical evidence to attempt the best digital- marketing performance to utilize the digital- wallet more broadly in business transactions. (Cooper \& Sommer, 2016; Lindsjørn, Sjøberg, Dingsøyr, Bergersen, \& Dybå, 2016)

Many the digital- wallet have the organizational policy-change because of the global- pandemic within very poor-process in the firms and it could have an impact to the digital-marketing- performance to improve the business-value and the customer loyalty as the task performance in marketing divisions. (Day et al., 2017; Landers, Bauer, \& Callan, 2017; Stock, 2016; Tse, Huang, \& Lam, 2013) Furthermore, the purpose of this research would be conduct with the synthesis the new- research model to fulfilling of research gap to pursue the distinctive marketing- performance and the costumers value co- creation to improve the customer- loyalty. (Greer, Lusch, \& Vargo, 2016; Vargo et al., 2017; Vargo \& Lusch, 2017)

Hence, the focus of the latent variables in this inquiries as develop the determinant to leads the digitalmarketing performance and consumer value co-creation to leads the customer's loyalty in the digitalwallet.(Demirkan \& Spohrer, 2014; Geraerdts, 2012; Järvinen \& Karjaluoto, 2015; Kasper-Brauer \& Leischnig, 2016; Kianto, Sáenz, \& Aramburu, 2017; Kim, Cavusgil, \& Cavusgil, 2013; Landroguez, 2013; G. Latham, Seijts, \& Slocum, 2016; Li, 2010; Malik, Pereira, \& Budhwar, 2017; Matošková \& Směšná, 2017; Nicole, Vaughan, Zabihullah, \& Mei, 2016; Obal \& Lancioni, 2013; Ouakouak \& 
Ouedraogo, 2017; Pittino, Visintin, Lenger, \& Sternad, 2016; Rakesh, Narendra, \& Sandeep, 2017; Senichev, 2013; Stone, Deadrick, Lukaszewski, \& Johnson, 2015; H. a. B. Susilo, 2019; Walmsley, 2016; Xerri \& Reid, 2017)

The business within on the strategic of marketing- plan should not implement in the same time for many to pursue the digital- marketing- performance, customer value and loyalty. Moreover, the resources- advantage of the venture in entire the market- position for having the new- opportunity and leads the financial performance. (Lusch, Vargo, \& O’Brien, 2007) Actually, the business of the digital marketing- plan choices by the general- managers for yield the improvement of the customer loyalty that they utilize the digital-wallet. (Bravo, Matute, \& Pina, 2015; Kang \& Lam, 2016; Mullen, Kelloway, \& Teed, 2017; Raybould \& Wilkins, 2006; Sambasivan, Abdul, \& Yusop, 2009). (Hamilton, 2011; Poisson-de Haro \& Bitektine, 2015; Reid \& Brady, 2012; Z. Wang, Sharma, \& Cao, 2016) (Khaq, 2020).

\section{LITERATURE REVIEW AND THE HYPOTHESIS}

Recently, the many scholars has inquiry the research- goal setting model to pursue the digitalmarketing performance conducted within the contributions for the body of knowledge on the goal setting theory of the digital- wallet firms for the competitions, but also for the giving the contributions of the management implications to make the organization strategies within entire for develop the business- marketing plan for the future long- run in business activities and adopted the wellmanagement practice on the marketing- leadership development.(Vargo \& Lusch, 2017) (Corsaro, Ramos, Henneberg, \& Naudé, 2011; del Alonso-Almeida, Bagur-Femenías, \& Llach, 2013; Mitchell $\&$ Bruno, 2016; Xu et al., 2019). Furthermore, in this investigate for doing the mapping corporate in the competitiveness advantage in the digital-wallet firms in Jakarta that could leads the superior digital marketing- performance, value and customer loyalty in business for the long- run and could to anticipated the pandemic situations. (Estrada, Faems, \& de Faria, 2016; Greer et al., 2016; Ivens, Pardo, Niersbach, \& Leischnig, 2016).

\section{The Service Dominant Logic and the Goal Setting Theory also the Contributions on Body of Knowledge}

The scholars could have rooted from the SDL and the GST as the mediators factors (e.g.; direction, effort, persistence and task marketing strategy) for develop the business of marketing strategies in the digital- wallet in Jakarta and to pursue the digital- marketing performance to attempt the value and customer loyalty. (Bravo et al., 2015; Fink, Yogev, \& Even, 2016; Ivanova \& Ivanov, 2015; Iyer, Hong Xiao, Sharma, \& Nicholson, 2015; Vargo \& Lusch, 2017; Xu et al., 2019) Hence, the marketing performance in the digital wallet within entire the sales-person experience of the venture for facing its competitions and the global pandemics' situations in many industries in the after global-pandemic situations passed.(Hult, Ketchen Jr, \& Reus, 2001; Javad Khazaei, Masood, \& Ezat Amirbakzadeh, 
2017; Mitchell \& Bruno, 2016; Mitrega, 2012). Furthermore, the GST- theory have facing the competition among firm in heterogeneous business in the digital- wallet firms performance and the sustainable competitive advantage to create the digital- marketing strategy policy, and increased the digital- marketing performance based on the marketing- complex task of the entire firms in Jakarta.(Alisher Tohirovich, Changjoon, \& Junghyun, 2017; Becherer, Helms, \& McDonald, 2012; Chen \& Latham, 2014; Gabrielsson, Seppälä, \& Gabrielsson, 2016; Shelby D. Hunt, 2013, 2015; Shelby D Hunt \& Morgan, 1995; Krausert, 2017; Kumar \& Yakhlef, 2016; Nor Shahriza Abdul, Mohamed Jalaldeen Mohamed, \& Norshidah, 2012; Stan De, Monique, \& Guy Van, 2017; C.-J. Wang, Tsai, \& Tsai, 2014; Xiaohong, Chengfeng, Yanbo, \& Gaowen, 2015; Zhao, Feng, \& Wang, 2015)

The Service- Dominant Logic theory within the original scope such as (Hult, 2011), says that the SDL theory could implies to customers offering, recognize that it conducts to the customers as a coproduced and consumers involvement to pursue the well customer fit with the customer needs. Subsequently, the level of implies to customers offering and customer fit as they needs, the scholars should be understand of the foundational premises such as; 1 ). The service was fundamental basis of exchange and indirect exchange mask, 2) The goods are a distribution within the mechanism within newest technologies for service provision and operant resources to pursue the competitive advantage and service-economies. 3). The role of among customers such as become a co-creator of products value and not provide by among firms but still as enterprise driven within firms' value platform, 4). The customers oriented and relational were inherently to improve within a service centered view and, 5 ). The uniquely value and phenomenological should provide to among customers and the economic actors resources. (Vargo et al., 2017; Vargo \& Lusch, 2017) (Vargo \&Lusch, 2010)

Recently, the marketing insights of the S-DL theory that the point of the knowledge as the fundamental source to attempt strong fundamental source of competitive advantage of entire the firms in Jakarta of deliver several S-DL direct implications of services. Furthermore, the firm's resources should upgrade more intensively the knowledge as the competitive advantage foundation and the urgently of primarily- flow of many well information's to the value and consumer's loyalty consumers and conduct to the new-market within the emergence market base on the marketing research on wellmarket management. Finally, based on Vargo and Lusch (2004), the scholar should determine about the toward S-DL by increased within focused of the management business- process to deliver consumer- value and the task of the firms resources within more uniquely. (Greer et al., 2016; Lusch et al., 2007; Vargo, Wieland, \& Akaka, 2015)

\section{The Framework and Hypothesis}

Indeed, the research framework of pursue the customer loyalty to utilized digital- wallet within the firms in Jakarta should be to develop for fulfillment the research gap for finding and to an evolved of 
marketing science to improvement the digital-marketing performance and customer value co-creation that conducted within customer loyalty to improve utilized the digital- wallet in Jakarta. (Chiang \& Birtch, 2010; Gupta, Singh, \& Bhattacharya, 2017; Mohamed, 2016; Munir, Rahman, Malik, \& Ma'amor, 2012; Silva, Gerwe, \& Becerra, 2017; H. a. B. Susilo, 2019; Vargo et al., 2015).

Subsequent to this global pandemic- business situation that conducted within the digital-marketing performance to increased the utilize the digital-wallet, and the scholars would have about the goal setting difficulty to increase more value and the customer loyalty. (Greer et al., 2016; Vargo \& Lusch, 2017). Therefore, the firms should determine some well mechanism to attempt the digital-marketing performance and achieving the goal within innovation effort in digital- marketing and persistence based and also task marketing effective strategies that among salesperson seeks out the brilliant ways to achieve the sustainable goal setting to pursue the value creation within Intellectual capital, Digital technology quality, and the Customer knowledge.(Vargo et al., 2017) (Deschamps \& Mattijs, 2017; Gutt, von Rechenberg, \& Kundisch, 2020; Landers et al., 2017; Santos, Basso, Kimura, \& Kayo, 2014; $\mathrm{Xu}$ et al., 2019; Yulius, 2019)

Furthermore, the scheme of research- framework to attempt the consumer loyalty as follow figures 1, below:

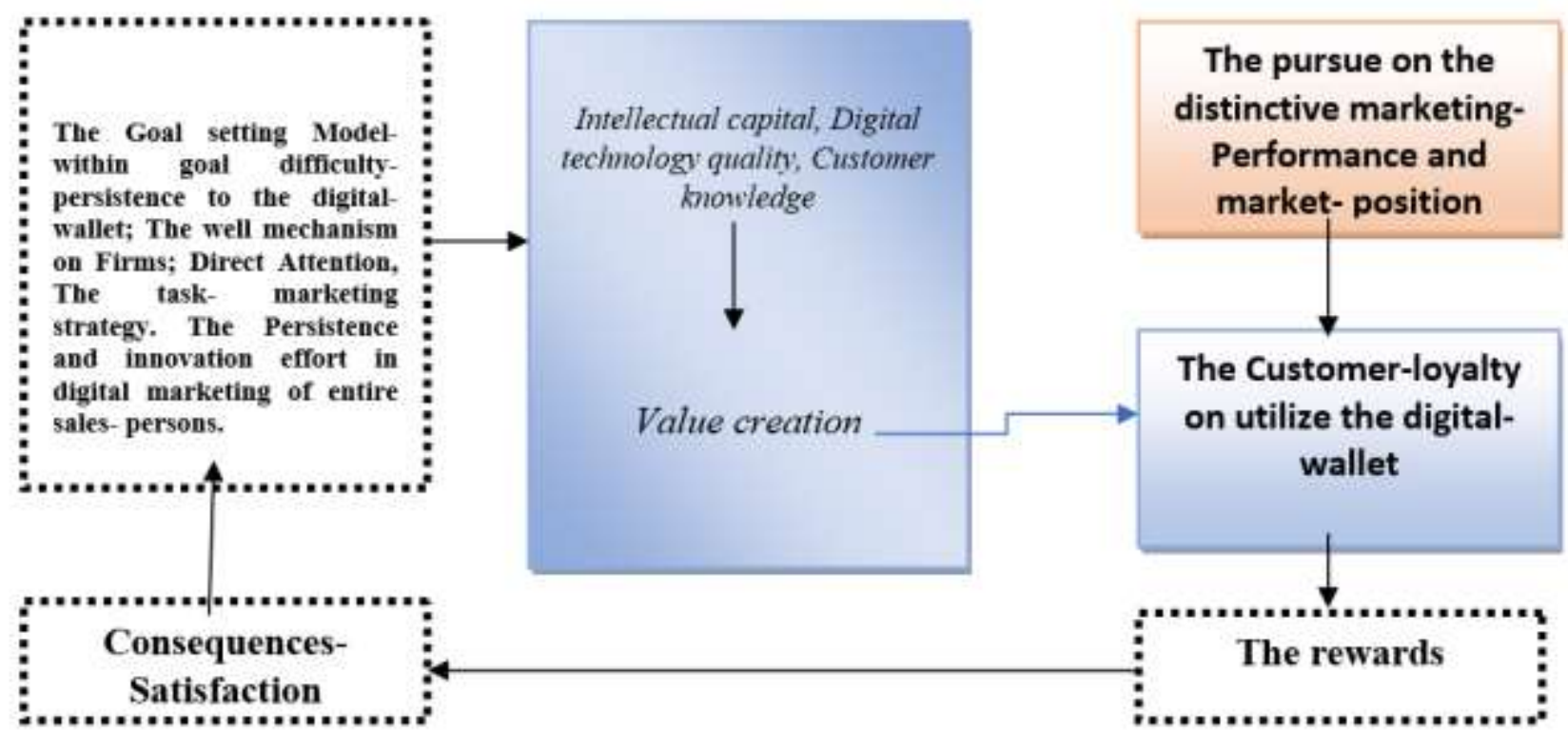

Fig.1 The Research Model to Pursue Customer- Loyalty of the utilize the digital- wallet in Jakarta

(Source: Develop from an Author) 
The hypothesis in these studies of the conceptual research model, as follow:

H1: The pursue of well mechanism- factors and the value creation within the digital-wallet is positively related to the distinctive of the customer loyalty in Jakarta.

\section{Research method}

The respondent, data collection and the measurement of entire latent variables

The sample frame as the target populations within 255 respondent for this research conducted within random sampling technique within entire loyalty consumer to utilize the digital- wallet in Jakarta (Borenstein, Hedges, Higgins, \& Rothstein, 2009; Hertwig \& Pleskac, 2010; Mathwick, Wagner, \& Unni, 2010; W. H. Susilo, 2020b; Thomas, 2013; Vos, Schiele, \& Hüttinger, 2016). Hence, the field research survey was utilities within the self administered questionnaire that should measures within the rating scale ( 1 to 5 rating independently scale) to among latent variables to make the response for distinctive- marketing performance in budget- hotel in Jakarta (Samson, Gloet, \& Singh, 2017; Stundziene, Startiene, Remeikiene, \& Dapkus, 2015; W. H. Susilo, 2020a) (Sekaran and Bougie, 2016).

Thus, the tools- marketing research instrument have the independently collected method and conducted with the rating scale as an interval data scale ( 1 to 5 very agree) and could transformed inti the continuous data within SEM procedure. Moreover, the reliability testing of among latent variables that the marketing-research model pertain; an Intellectual capital, digital technology quality, customer knowledge, value creation, and the customer loyalty could the following table 2, as below:

Table 2. The Reliability test of entire latent variables

\begin{tabular}{|c|l|c|c|}
\hline No & \multicolumn{1}{|c|}{ The latent variables } & Alpha- Cronbach & \multirow{2}{*}{ ok } \\
\hline 1 & Intellectual capital & 0,952 & \\
\hline 2 & Digital technology quality & 0,974 & \\
\hline 3 & Customer knowledge & 0,985 & \\
\hline 4 & Value creation & 0,983 & \\
\hline 5 & Customer loyalty & 0,981 & \\
\hline
\end{tabular}

Source: the prime data, 2020

Moreover, the validity and reliability among latent- variables marketing-model and also the model should have the goodness of fitting the confirmatory factor analysis modeling that conducted to the measurement model and the structural equation modeling phase, entire the latent variables and its dimensions as the second order also the goodness of fit indexes modeling, as follow the table 3 below (Agostini, Nosella, \& Filippini, 2016; Ghozali, 2013; Jangl, 2016; W. H. Susilo, 2020a) (Hair, Black, Babin and Anderson, 2010)(Evermann \& Tate, 2016): 
Table 3. The Construct Reliability and Variance Extracted

\begin{tabular}{|c|c|c|c|c|c|c|c|c|c|c|c|}
\hline \multirow[b]{2}{*}{$\begin{array}{c}\text { Vari } \\
\text { able } \\
\quad \mathrm{s}\end{array}$} & \multirow[b]{2}{*}{$\begin{array}{c}\text { Indi } \\
\text { cato } \\
\text { rs }\end{array}$} & \multirow[b]{2}{*}{ SFL } & \multirow[b]{2}{*}{ Error } & \multicolumn{4}{|c|}{ Construct Reliability } & \multicolumn{3}{|c|}{ Variance Extracted } & \multirow[b]{2}{*}{ Remark } \\
\hline & & & & $\begin{array}{c}\sum_{\text {STd. }} \\
\text { Loadi } \\
\text { ng }\end{array}$ & $\begin{array}{c}\left(\sum\right. \\
\text { STd. } \\
\text { Loadi } \\
\text { ng) }{ }^{2}\end{array}$ & $\sum_{\text {Error }}^{\sum}$ & $\begin{array}{c}\text { Nilai } \\
\text { CR }\end{array}$ & $\begin{array}{l}\text { Standard } \\
\text { Loading }^{2}\end{array}$ & $\begin{array}{c}\sum_{\text {Stdd. }} \\
\text { Loadi } \\
\text { ng) }{ }^{2}\end{array}$ & $\mathbf{V E}$ & \\
\hline \multicolumn{12}{|c|}{ Intellectual Capital } \\
\hline \multirow[t]{3}{*}{ HR } & IC1 & 0,87 & 0,25 & \multirow{8}{*}{6,85} & \multirow{8}{*}{46,92} & \multirow{8}{*}{2,11} & \multirow{8}{*}{$\mathbf{0 , 9 5}$} & 0,75 & \multirow{8}{*}{5,82} & \multirow{8}{*}{$\mathbf{0 , 7 3}$} & \multirow{8}{*}{ Reliable } \\
\hline & $\mathrm{IC} 2$ & 0,86 & 0,26 & & & & & 0,73 & & & \\
\hline & IC3 & 0,78 & 0,39 & & & & & 0,60 & & & \\
\hline \multirow[t]{3}{*}{ MS } & $\begin{array}{c}\text { MST } \\
1\end{array}$ & 0,84 & 0,29 & & & & & 0,70 & & & \\
\hline & $\begin{array}{c}\text { MST } \\
2\end{array}$ & 0,88 & 0,23 & & & & & 0,77 & & & \\
\hline & $\begin{array}{c}\text { MST } \\
3\end{array}$ & 0,86 & 0,26 & & & & & 0,73 & & & \\
\hline \multirow[t]{2}{*}{ MS } & $\begin{array}{c}\text { MSS } \\
1\end{array}$ & 0,91 & 0,16 & & & & & 0,82 & & & \\
\hline & $\begin{array}{c}\text { MSS } \\
2 \\
\end{array}$ & 0,85 & 0,27 & & & & & 0,72 & & & \\
\hline \multicolumn{12}{|c|}{ Digital Technology Quality } \\
\hline \multirow[t]{2}{*}{$\begin{array}{l}\text { Tang } \\
\text { ible }\end{array}$} & $\begin{array}{c}\text { TAN } \\
1 \\
\end{array}$ & 0,92 & 0,15 & \multirow{12}{*}{11,55} & \multirow{12}{*}{133,4} & \multirow{12}{*}{2,71} & \multirow{12}{*}{$\mathbf{0 , 9 8}$} & 0,84 & \multirow{12}{*}{10,21} & \multirow{12}{*}{$\mathbf{0 , 7 8}$} & \multirow{12}{*}{ Reliable } \\
\hline & $\begin{array}{c}\text { TAN } \\
2 \\
\end{array}$ & 0,92 & 0,15 & & & & & 0,84 & & & \\
\hline \multirow{3}{*}{$\begin{array}{c}\text { Reli } \\
\text { abili } \\
\text { ty }\end{array}$} & $\begin{array}{c}\text { REL } \\
1 \\
\end{array}$ & 0,87 & 0,25 & & & & & 0,75 & & & \\
\hline & $\begin{array}{c}\text { REL } \\
2 \\
\end{array}$ & 0,92 & 0,15 & & & & & 0,84 & & & \\
\hline & $\begin{array}{c}\text { REL } \\
3\end{array}$ & 0,87 & 0,24 & & & & & 0,75 & & & \\
\hline \multirow{3}{*}{$\begin{array}{c}\text { Resp } \\
\text { onsi } \\
\text { vene } \\
\text { ss }\end{array}$} & $\begin{array}{c}\text { RES } \\
1\end{array}$ & 0,88 & 0,23 & & & & & 0,77 & & & \\
\hline & $\begin{array}{c}\text { RES } \\
2 \\
\end{array}$ & 0,81 & 0,35 & & & & & 0,65 & & & \\
\hline & $\begin{array}{c}\text { RES } \\
3 \\
\end{array}$ & 0,86 & 0,27 & & & & & 0,73 & & & \\
\hline \multirow{3}{*}{$\begin{array}{c}\text { Assu } \\
\text { ranc } \\
\text { es }\end{array}$} & $\begin{array}{c}\text { ASR } \\
1 \\
\end{array}$ & 0,85 & 0,28 & & & & & 0,72 & & & \\
\hline & $\begin{array}{c}\text { ASR } \\
2 \\
\end{array}$ & 0,92 & 0,15 & & & & & 0,84 & & & \\
\hline & $\begin{array}{c}\text { ASR } \\
3 \\
\end{array}$ & 0,90 & 0,18 & & & & & 0,81 & & & \\
\hline $\begin{array}{l}\text { Emp } \\
\text { athy }\end{array}$ & $\begin{array}{c}\text { EMP } \\
1\end{array}$ & 0,94 & 0,11 & & & & & 0,88 & & & \\
\hline
\end{tabular}




\begin{tabular}{|c|c|c|c|c|c|c|c|c|c|c|c|}
\hline \multirow{3}{*}{$\begin{array}{c}\text { Vari } \\
\text { able } \\
\text { s }\end{array}$} & \multirow[b]{2}{*}{$\begin{array}{c}\text { Indi } \\
\text { cato } \\
\text { rs }\end{array}$} & \multirow[b]{2}{*}{ SFL } & \multirow[b]{2}{*}{ Error } & \multicolumn{4}{|c|}{ Construct Reliability } & \multicolumn{3}{|c|}{ Variance Extracted } & \multirow{3}{*}{ Remark } \\
\hline & & & & \multirow[t]{2}{*}{$\begin{array}{c}\sum_{\text {STd. }} \\
\text { Loadi } \\
\text { ng }\end{array}$} & \multirow[t]{2}{*}{$\begin{array}{c}\left(\sum\right. \\
\text { STd. } \\
\text { Loadi } \\
\text { ng) }{ }^{2}\end{array}$} & \multirow[t]{2}{*}{$\sum_{\text {Error }}$} & \multirow[t]{2}{*}{$\begin{array}{l}\text { Nilai } \\
\text { CR }\end{array}$} & $\begin{array}{l}\text { Standard } \\
\text { Loading }^{2}\end{array}$ & $\begin{array}{c}\sum_{\text {(Std. }} \\
\text { Loadi } \\
\text { ng) }\end{array}$ & VE & \\
\hline & $\begin{array}{c}\text { EMP } \\
2 \\
\end{array}$ & 0,89 & 0,20 & & & & & 0,79 & & & \\
\hline \multicolumn{12}{|c|}{ Customer Knowledge } \\
\hline \multirow[t]{3}{*}{$\mathrm{KP}$} & $\begin{array}{c}\text { KPR } \\
1 \\
\end{array}$ & 0,94 & 0,11 & \multirow{12}{*}{11,28} & \multirow{12}{*}{127,23} & \multirow{12}{*}{1,27} & \multirow{12}{*}{$\mathbf{0 , 9 9}$} & 0,88 & \multirow{12}{*}{10,57} & \multirow{12}{*}{$\mathbf{0 , 8 9}$} & \multirow{12}{*}{ Reliable } \\
\hline & $\begin{array}{c}\text { KPR } \\
2 \\
\end{array}$ & 0,93 & 0,14 & & & & & 0,86 & & & \\
\hline & $\begin{array}{c}\text { KPR } \\
3\end{array}$ & 0,94 & 0,12 & & & & & 0,88 & & & \\
\hline \multirow[t]{3}{*}{$\mathrm{PP}$} & $\begin{array}{c}\mathrm{PPE} \\
1 \\
\end{array}$ & 0,94 & 0,12 & & & & & 0,88 & & & \\
\hline & $\begin{array}{c}\text { PPE } \\
2 \\
\end{array}$ & 0,94 & 0,11 & & & & & 0,88 & & & \\
\hline & $\begin{array}{c}\text { PPE } \\
3 \\
\end{array}$ & 0,93 & 0,14 & & & & & 0,86 & & & \\
\hline \multirow[t]{3}{*}{$\mathrm{TP}$} & $\begin{array}{c}\text { TPE } \\
1 \\
\end{array}$ & 0,95 & 0,09 & & & & & 0,90 & & & \\
\hline & $\begin{array}{c}\text { TPE } \\
2 \\
\end{array}$ & 0,94 & 0,12 & & & & & 0,88 & & & \\
\hline & $\begin{array}{c}\text { TPE } \\
3 \\
\end{array}$ & 0,93 & 0,14 & & & & & 0,86 & & & \\
\hline \multirow[t]{3}{*}{$\mathrm{KE}$} & $\begin{array}{c}\text { KEF } \\
1 \\
\end{array}$ & 0,90 & 0,18 & & & & & 0,81 & & & \\
\hline & $\begin{array}{c}\text { KEF } \\
2 \\
\end{array}$ & 0,98 & 0,04 & & & & & 0,96 & & & \\
\hline & $\begin{array}{c}\mathrm{KEF} \\
3\end{array}$ & 0,96 & 0,08 & & & & & 0,92 & & & \\
\hline \multicolumn{12}{|c|}{ Value Creation } \\
\hline \multirow[t]{3}{*}{$\mathrm{NE}$} & $\begin{array}{c}\text { NEK } \\
1 \\
\end{array}$ & 0,97 & 0,06 & \multirow{9}{*}{11,06} & \multirow{9}{*}{122,32} & \multirow{9}{*}{1,79} & \multirow{9}{*}{$\mathbf{0 , 9 8}$} & 0,94 & & & \\
\hline & $\begin{array}{c}\text { NEK } \\
2 \\
\end{array}$ & 0,95 & 0,10 & & & & & 0,90 & & & \\
\hline & $\begin{array}{c}\text { NEK } \\
3 \\
\end{array}$ & 0,96 & 0,09 & & & & & 0,92 & & & \\
\hline \multirow[t]{3}{*}{ NB } & $\begin{array}{c}\text { NBI } \\
1 \\
\end{array}$ & 0,91 & 0,16 & & & & & 0,82 & & & \\
\hline & $\begin{array}{c}\text { NBI } \\
2 \\
\end{array}$ & 0,91 & 0,17 & & & & & 0,82 & 11,74 & 0,86 & Reliable \\
\hline & $\begin{array}{c}\text { NBI } \\
3 \\
\end{array}$ & 0,90 & 0,18 & & & & & 0,81 & & & \\
\hline $\mathrm{NP}$ & $\begin{array}{c}\text { NPE } \\
1\end{array}$ & 0,94 & 0,13 & & & & & 0,88 & & & \\
\hline & $\begin{array}{c}\text { NPE } \\
2\end{array}$ & 0,88 & 0,22 & & & & & 0,77 & & & \\
\hline $\mathrm{NE}$ & NES & 0,90 & 0,18 & & & & & 0,81 & & & \\
\hline
\end{tabular}




\begin{tabular}{|c|c|c|c|c|c|c|c|c|c|c|c|}
\hline \multirow[b]{2}{*}{$\begin{array}{c}\text { Vari } \\
\text { able } \\
\text { s }\end{array}$} & \multirow[b]{2}{*}{$\begin{array}{l}\text { Indi } \\
\text { cato } \\
\text { rs }\end{array}$} & \multirow[b]{2}{*}{ SFL } & \multirow[b]{2}{*}{ Error } & \multicolumn{4}{|c|}{ Construct Reliability } & \multicolumn{3}{|c|}{ Variance Extracted } & \multirow[b]{2}{*}{ Remark } \\
\hline & & & & \multirow[t]{2}{*}{$\begin{array}{c}\sum_{\text {STd. }} \\
\text { Loadi } \\
\text { ng }\end{array}$} & $\begin{array}{c}\quad \sum \\
\text { STd. } \\
\text { Loadi } \\
\text { ng) }{ }^{2}\end{array}$ & $\sum_{\text {Error }}$ & $\begin{array}{c}\text { Nilai } \\
\text { CR }\end{array}$ & $\begin{array}{l}\text { Standard } \\
\text { Loading }^{2}\end{array}$ & $\begin{array}{c}\sum_{\text {(Std. }} \\
\text { Loadi } \\
\text { ng) })^{2}\end{array}$ & $\mathbf{V E}$ & \\
\hline & 1 & & & & & & & & & & \\
\hline & $\begin{array}{c}\text { NES } \\
2\end{array}$ & 0,88 & 0,22 & & & & & 0,77 & & & \\
\hline & $\begin{array}{c}\text { NES } \\
3\end{array}$ & 0,94 & 0,12 & & & & & 0,88 & & & \\
\hline & $\begin{array}{c}\text { NES } \\
4\end{array}$ & 0,92 & 0,16 & & & & & 0,84 & & & \\
\hline \multicolumn{12}{|c|}{ Customer Loyalty } \\
\hline \multirow[t]{2}{*}{$\mathrm{K}$} & $\begin{array}{c}\text { KES } \\
1\end{array}$ & 0,94 & 0,12 & \multirow{6}{*}{5,76} & \multirow{6}{*}{33,17} & \multirow{6}{*}{0,51} & \multirow{6}{*}{$\mathbf{0 , 9 8}$} & 0,88 & \multirow{6}{*}{5,52} & \multirow{6}{*}{0,91} & \multirow{6}{*}{ Reliable } \\
\hline & $\begin{array}{c}\text { KES } \\
2\end{array}$ & 0,96 & 0,08 & & & & & 0,92 & & & \\
\hline \multirow[t]{2}{*}{ KB } & $\begin{array}{l}\text { KB } \\
\text { A1 }\end{array}$ & 0,95 & 0,10 & & & & & 0,90 & & & \\
\hline & $\begin{array}{l}\text { KB } \\
\text { A2 } \\
\end{array}$ & 0,96 & 0,09 & & & & & 0,92 & & & \\
\hline \multirow[t]{2}{*}{ B } & $\begin{array}{c}\text { BER } \\
1\end{array}$ & 0,99 & 0,03 & & & & & 0,98 & & & \\
\hline & $\begin{array}{c}\text { BER } \\
2\end{array}$ & 0,96 & 0,09 & & & & & 0,92 & & & \\
\hline
\end{tabular}

Source: SEM Lisrel- prime data, 2020

Furthermore, the definition operational of the entire latent variables determine within based on the SDL and GST- to an attain of the goal difficulty that the extent to which goal is challenging and requires and would lead the well mechanism that conducted within the Intellectual capital, digital technology quality, customer knowledge, value creation, and also the customer loyalty. (Landers et al., 2017; G. P. Latham, 2016; Vargo et al., 2017; Vargo \& Lusch, 2017). In particular, the pursue on the distinctive marketing performance and the market position-competitive advantage that measured by the very knowledgeable salesperson and an efficient production process that it could pursue the consumer value creation and the customer loyalty within the digital wallet firms in Jakarta. (Ferdinand \& Fitriani, 2015; Greer et al., 2016; Shelby D. Hunt, 2015; Sugiyarti, Ferdinand, \& Nurchayati, 2018)

\section{RESULT AND DISCUSSION}

\section{The Hypothesis testing}

The conceptual marketing research model- pursue the consumer value creation and the customer loyalty within the digital wallet firms in these inquiries have the analysis that should be conduct to the structural equation modeling, cause an entire the latent constructs were un-observed characteristics. (W. H. Susilo, 2020b; Vargo et al., 2017). Moreover, the two phase approach have pertains; measurement model and the structural hybrid full model of the consumer value creation and the 
customer loyalty within the digital wallet firms in Jakarta that it conducted to the confirmatory strategies in this multivariate data analysis, with a testing the validity and the reliability among latentvariables, and then the synthesis the fitting model and hypothesis confirmed (Ghozali, 2013; Greer et al., 2016; W. H. Susilo, 2020b; Vargo, Maglio, \& Akaka, 2008)(Susilo and Yulius, 2017), as follow figure 2 below.

Actually, the research result would have for the data analysis pertain: the sensitivity analysis; the test indicated did not have the outlier and missing value that conducted with SPSS and the $\mathrm{z}$ value $<2.50$ and the univariate and the multivariate of normality test (W. H. Susilo, 2020b).

However, the goodness of fit research model in this investigated could be analyzed within the entire an indexed value (W. H. Susilo, 2020a). Moreover, an among hypothesis confirmed was conducted with t value >2. (Augusty, 2014; W. H. Susilo, 2016, 2020b). In the global-pandemic situation the researcher would conducted within the simulations- data to the entire latent variables that it was determinant on the standard error of means, standard deviation and the amount of the samples and also the confident intervals (CI-95\%) (W. H. Susilo, 2020a, 2020c). Actually, the hybrid model of pursue the consumer value creation and the customer loyalty within the digital wallet firms in Jakarta could show the figure 2 as below: 


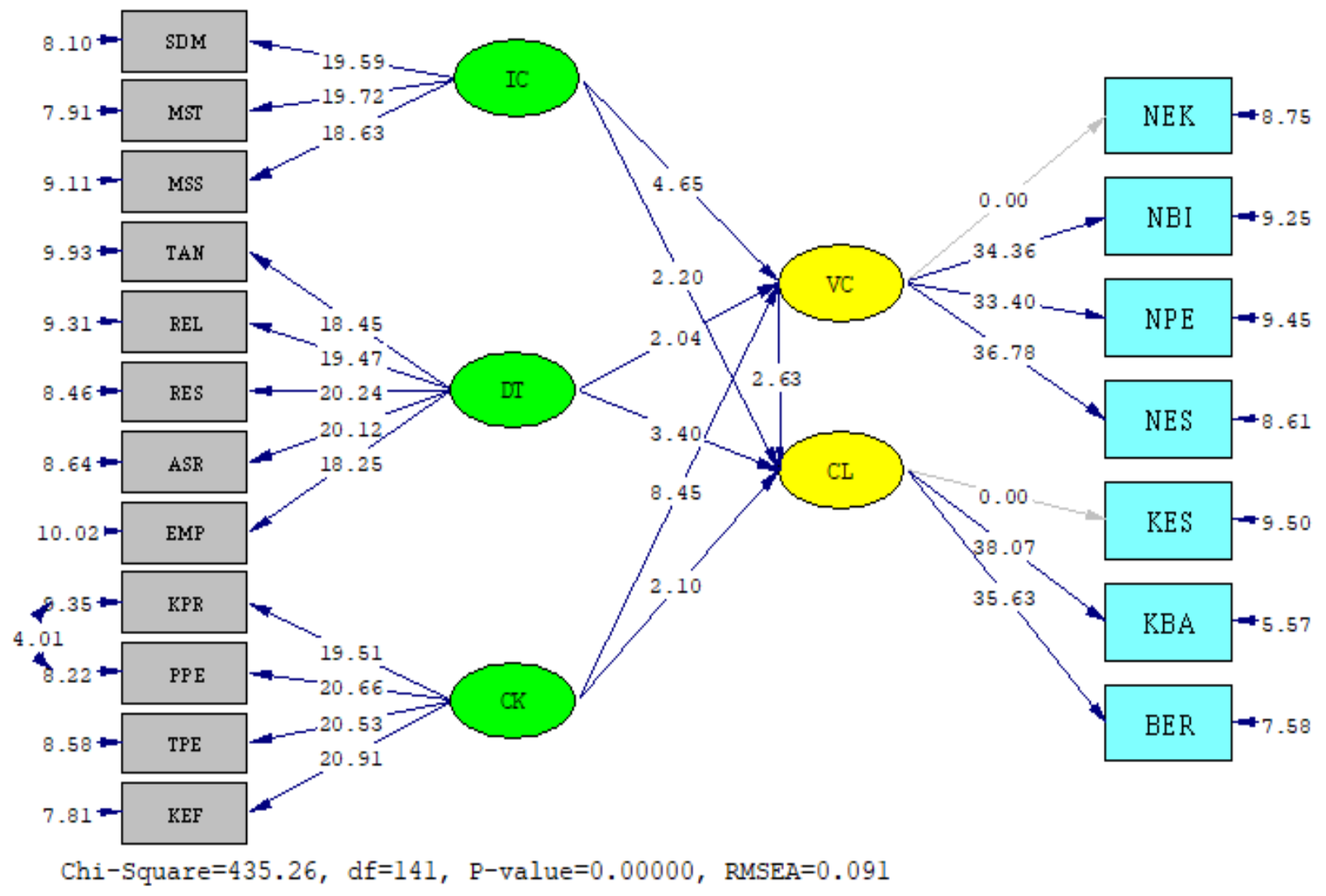

Figure 2. The hybrid model of pursue the consumer value creation (VC) and the customer loyalty (CL) within the digital wallet firms in Jakarta

Actually, the most confirmed of the hybrid- marketing model of pursue the consumer value creation (VC) and the customer loyalty (CL) within the digital wallet firms in Jakarta could showed and conducted with the impact of $\mathrm{CK}$ to VC. Moreover, the evidence base on the consumer knowledge (CK) that could improve the value creation (VC), that it was indicated that the among Consumer need more information from the entire firms for achievement of the consumer loyalty within the utilize of the digital wallet in Jakarta. (Almeida-Santana \& Moreno-Gil, 2017; Obal \& Lancioni, 2013; Sedera, Lokuge, Grover, Sarker, \& Sarker, 2016; Tate, Bongiovanni, Kowalkiewicz, \& Townson, 2018)

\section{CONCLUSIONS AND RESEARCH CONTRIBUTION.}

Indeed, the entire hypotheses was confirmed the entire hypotheses testing, and the value should be having to pursue the consumer value creation (VC) and the customer loyalty (CL) within the digital wallet firms in Jakarta; (1) Intellectual capital has confirmed on value creation in consumers who use OVO digital wallets; (2) Digital technology quality confirmed the value creation in consumers who use OVO digital wallets; (3) Customer knowledge confirmed value creation in consumers who use OVO digital wallets; (4) Intellectual capital confirmed customer loyalty to consumers who use OVO 
digital wallets; (5) Digital quality technology has confirmed on customer loyalty to consumers who use OVO digital wallets; (6) Customer knowledge confirmed customer loyalty to consumers who use OVO digital wallets; (7). The Value creation confirmed customer loyalty to consumers who use OVO digital wallets.

The hybrid- marketing model of the determinant to consumer value creation (VC) and the customer loyalty (CL) within the digital wallet firms in Jakarta could gave the body of knowledge of the SDL theory that the marketing- model could pursue positively and confirmed the achievement of customer loyalty within re-purchase some product utilized the digital wallet in Jakarta.(Mishra, 2016; Reydet \& Carsana, 2017; Smith \& Smith, 2019) The limitation in data survey within the global-pandemic to gain more respondents to participate was to limited, that the scholars could utility the simulations-data within normal distributions.

Finally, to the future research, the scholars could add some latent variables as the digitalize planning, building the relationship within firms and consumers, building digital culture, the service- advance of the product, the stability of the internet connection and more hi-tech fixture of the product. (Kianto et al., 2017; Obal \& Lancioni, 2013)

\section{Acknowledgement}

Thank you so much to the New-Expertise and Experience Learning Club, Faculty of Economics and Business and Management- Management, University of Persada Indonesia Y.A.I. To my colleague and doctoral- postgraduate students. To in Kind Workshops NEW E\&EL CLUB LABORATORY FEB UPI Y.A.I team.

\section{Declaration of conflicting interests}

The scholar declared no potential conflicts of interest with respect to the investigated, authorship, publication within this manuscript.

\section{Funding}

The author did not receive the financial support for this research and publication of this manuscript.

ORCID iD: ORCID:000-0002-6758-1159, URL: orcid.org/0000-0002. And SCOPUS ID: 56539508300 .

\section{REFERENCES}

Agostini, L., Nosella, A., \& Filippini, R. (2016). Towards an Integrated View of the Ambidextrous Organization: A Second-Order Factor Model. Creativity and Innovation Management, 25(1), 129-141. doi: 10.1111/caim.12167 
Alisher Tohirovich, D., Changjoon, R., \& Junghyun, Y. (2017). Organizational structure and innovation performance: Is employee innovative behavior a missing link? Career Development International, 22(4), 334-350. doi: 10.1108/CDI-12-2016-0234

Almeida-Santana, A., \& Moreno-Gil, S. (2017). New trends in information search and their influence on destination loyalty: Digital destinations and relationship marketing. Journal of Destination Marketing \& Management, 6(2), 150-161. doi: 10.1016/j.jdmm.2017.02.003

Augusty, F. (2014). Structural Equation Modelling Dalam Penelitian Manajemen: Fakultas Ekonomi dan Bisnis Universitas Diponegoro.

Becherer, R. C., Helms, M. M., \& McDonald, J. P. (2012). The Effect of Entrepreneurial Marketing on Outcome Goals in SMEs. New England Journal of Entrepreneurship, 15(1), 13.

Bitter, S., \& Grabner-Kräuter, S. (2016). Consequences of customer engagement behavior: when negative Facebook posts have positive effects. ElectronMarkets, 26, 13.

Borenstein, M., Hedges, L. V., Higgins, J. P. T., \& Rothstein, R. R. (2009). Fixed-effect vs Randomeffects Introduction to Meta Analysis: Johnn Willey and Sons.

Bravo, R., Matute, J., \& Pina, J. M. (2015). Corporate identity management in the banking sector: effects on employees' identification, identity attractiveness, and job satisfaction. Service Business, 10(4), 687-714. doi: 10.1007/s11628-015-0287-9

Chang, J. Y. T., Jiang, J. J., Klein, G., \& Wang, E. T. G. (2019). Enterprise system programs: Goal setting and cooperation in the integration team. Information \& Management, 56(6). doi: 10.1016/j.im.2018.12.005

Chen, X., \& Latham, G. P. (2014). The effect of priming learning vs. performance goals on a complex task. Organizational Behavior and Human Decision Processes, 125(2), 88-97. doi: 10.1016/j.obhdp.2014.06.004

Chiang, F. F. T., \& Birtch, T. A. (2010). Pay for performance and work attitudes: The mediating role of employee-organization service value congruence. International Journal of Hospitality Management, 29(4), 632-640. doi: 10.1016/j.ijhm.2009.11.005

Cooper, R. G., \& Sommer, A. F. (2016). Agile-Stage-Gate: New idea-to-launch method for manufactured new products is faster, more responsive. Industrial Marketing Management, 59, 167-180. doi: 10.1016/j.indmarman.2016.10.006

Corsaro, D., Ramos, C., Henneberg, S. C., \& Naudé, P. (2011). Actor network pictures and networking activities in business networks: An experimental study. Industrial Marketing Management, 40(6), 919-932. doi: 10.1016/j.indmarman.2011.06.028

Day, A., Crown, S. N., \& Ivany, M. (2017). Organisational change and employee burnout: The moderating effects of support and job control. Safety Science. doi: 10.1016/j.ssci.2017.03.004

del Alonso-Almeida, M. M., Bagur-Femenías, L., \& Llach, J. (2013). The adoption of quality management practices and their impact on business performance in small service companies: the case of Spanish travel agencies. Service Business, 9(1), 57-75. doi: 10.1007/s11628-0130218-6 
Demirkan, H., \& Spohrer, J. (2014). Developing a framework to improve virtual shopping in digital malls with intelligent self-service systems. Journal of Retailing and Consumer Services, 21(5), 860-868. doi: 10.1016/j.jretconser.2014.02.012

Deschamps, C., \& Mattijs, J. (2017). Sustainable goal setting: a large-scale case in management practice. International Journal of Productivity and Performance Management, 66(8), 10871104. doi: 10.1108/IJPPM-05-2016-0100

Estrada, I., Faems, D., \& de Faria, P. (2016). Coopetition and product innovation performance: The role of internal knowledge sharing mechanisms and formal knowledge protection mechanisms. Industrial Marketing Management, 53, 56-65. doi: 10.1016/j.indmarman.2015.11.013

Evermann, J., \& Tate, M. (2016). Assessing the predictive performance of structural equation model estimators. Journal of Business Research, 69(10), 4565-4582. doi: 10.1016/j.jbusres.2016.03.050

Ferdinand, A., \& Fitriani, L. (2015). Acculturative Iconic Product Attractiveness and Marketing Performance.

Fink, L., Yogev, N., \& Even, A. (2016). Business intelligence and organizational learning: An empirical investigation of value creation processes. Information \& Management. doi: 10.1016/j.im.2016.03.009

Fu, F. Q. (2009). EFFECTS OF SALESPERSON EXPERIENCE, AGE, AND GOAL SETTING ON NEW PRODUCT PERFORMANCE TRAJECTORY: A GROWH CURVE MODELING APPROACH. Journal of Marketing Theory and Practice, 17(1), 14.

Gabrielsson, M., Seppälä, T., \& Gabrielsson, P. (2016). Realizing a hybrid competitive strategy and achieving superior financial performance while internationalizing in the high-technology market. Industrial Marketing Management, 54, 141-153. doi: 10.1016/j.indmarman.2015.07.001

Geraerdts, R. (2012). Customer value creation: A journey in the search of excellence. Industrial Marketing Management, 41(1), 11-12. doi: 10.1016/j.indmarman.2011.11.023

Ghozali, I. (2013). Model Persamaan Structural, Konsep dan Aplikasi Dengan Program AMOS 21.0: Badan Penerbit Universitas Diponegoro.

Greer, C. R., Lusch, R. F., \& Vargo, S. L. (2016). A service perspective. Organizational Dynamics, 45(1), 28-38. doi: 10.1016/j.orgdyn.2015.12.004

Gupta, V., Singh, S., \& Bhattacharya, A. (2017). THE RELATIONSHIPS BETWEEN LEADERSHIP, WORK ENGAGEMENT AND EMPLOYEE INNOVATIVE PERFORMANCE: EMPIRICAL EVIDENCE FROM THE INDIAN R\&D CONTEXT. International Journal of Innovation Management, 21(07), 1750055. doi: 10.1142/S1363919617500554

Gutt, D., von Rechenberg, T., \& Kundisch, D. (2020). Goal achievement, subsequent user effort and the moderating role of goal difficulty. Journal of Business Research, 106, 277-287. doi: 10.1016/j.jbusres.2018.06.019 
Hamilton, R. T. (2011). How firms grow and the influence of size and age. International Small Business Journal, 30(6), 611-621. doi: 10.1177/0266242610383446

Harrigan, P., Evers, U., Miles, M. P., \& Daly, T. (2017). Customer engagement and the relationship between involvement, engagement, self-brand connection and brand usage intent. Journal of Business Research. doi: 10.1016/j.jbusres.2017.11.046

Hertwig, R., \& Pleskac, T. J. (2010). Decisions from experience: why small samples? Cognition, 115(2), 225-237. doi: 10.1016/j.cognition.2009.12.009

Hult, G. T. M., Ketchen Jr, D. J., \& Reus, T. H. (2001). Organizational learning capacity and internal customer orientation within strategic sourcing units. Journal of Quality Management, 6(2), 173-192. doi: http://dx.doi.org/10.1016/S1084-8568(01)00036-0

Hunt, S. D. (2013). A general theory of business marketing: R-A theory, Alderson, the ISBM framework, and the IMP theoretical structure. Industrial Marketing Management, 42(3), 283293. doi: 10.1016/j.indmarman.2013.02.002

Hunt, S. D. (2015). Marketing theory : foundations, controversy, strategy, resource-advantage theory. New York, USA: Routledge Taylor \& Francis Group.

Hunt, S. D., \& Morgan, R. M. (1995). The comparative advantage theory of competition. The Journal of Marketing, 1-15.

Ivanova, M., \& Ivanov, S. (2015). Affiliation to hotel chains: Hotels' perspective. Tourism Management Perspectives, 16, 148-162. doi: 10.1016/j.tmp.2015.08.001

Ivens, B. S., Pardo, C., Niersbach, B., \& Leischnig, A. (2016). Firm-internal key account management networks: Framework, case study, avenues for future research. Industrial Marketing Management, 58, 102-113. doi: 10.1016/j.indmarman.2016.05.019

Iyer, G. R., Hong Xiao, S., Sharma, A., \& Nicholson, M. (2015). Behavioral issues in price setting in business-to-business marketing: A framework for analysis. Industrial Marketing Management, 47, 6-16. doi: 10.1016/j.indmarman.2015.02.001

Jangl, P. (2016). Model of Market Orientation of High-Tech Firms in Germany: Validation Study. Verslas: teorija ir praktika, 17(3), 216-224. doi: 10.3846/btp.2016.643

Järvinen, J., \& Karjaluoto, H. (2015). The use of Web analytics for digital marketing performance measurement. Industrial Marketing Management. doi: 10.1016/j.indmarman.2015.04.009

Javad Khazaei, P., Masood, K., \& Ezat Amirbakzadeh, K. (2017). Linking internal marketing orientation to balanced scorecard outcomes in small businesses: the case of travel agencies. International Journal of Culture, Tourism and Hospitality Research, 11(3), 297-308. doi: 10.1108/IJCTHR-03-2016-0024

Kang, E. S. L., \& Lam, S. Y. (2016). Contingent effects of firm and employee reputations on professional advice adoption. Service Business. doi: 10.1007/s11628-016-0312-7

Kasper-Brauer, K., \& Leischnig, A. (2016). Yes, we can! A fuzzy-set analysis of challenges, skills, and enjoyment of work. Journal of Business Research, 69(11), 5286-5291. doi: 10.1016/j.jbusres.2016.04.126 
Khaq, S. a. S. (2020). An Increased on Firm Value: Insight in State Owned Enterprises that Listed on the Indonesia Stock Exchange 2013-2018. International Journal of Economic and Financial Issues, 10(2), 143-147. doi: http://doi.org/10.32479/ijefi.9219

Kianto, A., Sáenz, J., \& Aramburu, N. (2017). Knowledge-based human resource management practices, intellectual capital and innovation. Journal of Business Research, 81, 11-20. doi: 10.1016/j.jbusres.2017.07.018

Kim, D., Cavusgil, S. T., \& Cavusgil, E. (2013). Does IT alignment between supply chain partners enhance customer value creation? An empirical investigation. Industrial Marketing Management, 42(6), 880-889. doi: 10.1016/j.indmarman.2013.05.021

Krausert, A. (2017). HR differentiation between professional and managerial employees: Broadening and integrating theoretical perspectives. Human Resource Management Review, 27(3), 442457. doi: 10.1016/j.hrmr.2016.11.002

Kumar, N., \& Yakhlef, A. (2016). Managing business-to-business relationships under conditions of employee attrition: A transparency approach. Industrial Marketing Management, 56, 143-155. doi: 10.1016/j.indmarman.2016.01.002

Landers, R. N., Bauer, K. N., \& Callan, R. C. (2017). Gamification of task performance with leaderboards: A goal setting experiment. Computers in Human Behavior, 71, 508-515. doi: 10.1016/j.chb.2015.08.008

Landroguez, S. M. (2013). Developing an integrated vision of customer value. Journal of Services Marketing, 27(3), 234-244. doi: 10.1108/08876041311330726

Latham, G., Seijts, G., \& Slocum, J. (2016). The goal setting and goal orientation labyrinth. Organizational Dynamics, 45(4), 271-277. doi: 10.1016/j.orgdyn.2016.10.001

Latham, G. P. (2016). Goal setting: a possible theoretical framework for examining the effect of priming goals on organizational behavior. Current Opinion in Psychology, 12, 85-88. doi: 10.1016/j.copsyc.2016.07.005

Li, Y.-M. (2010). Pricing digital content distribution over heterogeneous channels. Decision Support Systems, 50(1), 243-257. doi: 10.1016/j.dss.2010.08.027

Lindsjørn, Y., Sjøberg, D. I. K., Dingsøyr, T., Bergersen, G. R., \& Dybå, T. (2016). Teamwork quality and project success in software development: A survey of agile development teams. Journal of Systems and Software, 122, 274-286. doi: 10.1016/j.jss.2016.09.028

Lusch, R. F., Vargo, S. L., \& O’Brien, M. (2007). Competing through service: Insights from servicedominant logic. Journal of Retailing, 83(1), 5-18. doi: 10.1016/j.jretai.2006.10.002

Malik, A., Pereira, V., \& Budhwar, P. (2017). Value creation and capture through human resource management practices. Organizational Dynamics. doi: 10.1016/j.orgdyn.2017.09.002

Mathwick, C., Wagner, J., \& Unni, R. (2010). Computer-Mediated Customization Tendency (CMCT) and the Adaptive e-Service Experience. Journal of Retailing, 86(1), 11-21. doi: 10.1016/j.jretai.2009.11.001 
Matošková, J., \& Směšná, P. (2017). Human resource management practices stimulating knowledge sharing. Management \& Marketing, 12(4). doi: 10.1515/mmcks-2017-0036

Mishra, A. (2016). An exploratory conceptualization of consumer design perception for digital devices. Journal of Indian Business Research, 8(2), 143-163. doi: doi:10.1108/JIBR-03-20150037

Mitchell, J. N., \& Bruno, D. (2016). Developing sustainable management theory: goal-setting theory based in virtue. Management Decision, 54(2), 304-320. doi: 10.1108/MD-05-2014-0312

Mitrega, M. (2012). Network partner knowledge and internal relationships influencing customer relationship

quality and company performance. Journal of Business \& Industrial Marketing, Vol. 27 / 6, pg. 486496. doi: 10.1108/08858621211251488

Mohamed, L. M. (2016). Assessing the effects of transformational leadership: A study on Egyptian hotel employees. Journal of Hospitality and Tourism Management, 27, 49-59. doi: 10.1016/j.jhtm.2016.04.001

Mullen, J., Kelloway, E. K., \& Teed, M. (2017). Employer safety obligations, transformational leadership and their interactive effects on employee safety performance. Safety Science, 91, 405-412. doi: 10.1016/j.ssci.2016.09.007

Munir, R. I. S., Rahman, R. A., Malik, A. M. A., \& Ma'amor, H. (2012). Relationship between Transformational Leadership and Employees' Job Satisfaction among the Academic Staff. Procedia - Social and Behavioral Sciences, 65, 885-890. doi: 10.1016/j.sbspro.2012.11.215

Nicole, D., Vaughan, C., Zabihullah, S., \& Mei, L. (2016). Workplace training and generic and technical skill development in the Australian construction industry. Journal of Management Development, 35(4), 486-504. doi: 10.1108/JMD-05-2015-0073

Nor Shahriza Abdul, K., Mohamed Jalaldeen Mohamed, R., \& Norshidah, M. (2012). Measuring employee readiness for knowledge management using intention to be involved with KM SECI processes. Business Process Management Journal, 18(5), 777-791. doi: $10.1108 / 14637151211270153$

Obal, M., \& Lancioni, R. A. (2013). Maximizing buyer-supplier relationships in the Digital Era: Concept and research agenda. Industrial Marketing Management, 42(6), 851-854. doi: 10.1016/j.indmarman.2013.06.002

Ouakouak, M. L., \& Ouedraogo, N. (2017). ANTECEDENTS OF EMPLOYEE CREATIVITY AND ORGANISATIONAL INNOVATION: AN EMPIRICAL STUDY. International Journal of Innovation Management, 21(07), 1750060. doi: 10.1142/S1363919617500608

Pittino, D., Visintin, F., Lenger, T., \& Sternad, D. (2016). Are high performance work practices really necessary in family SMEs? An analysis of the impact on employee retention. Journal of Family Business Strategy, 7(2), 75-89. doi: 10.1016/j.jfbs.2016.04.002 
Poisson-de Haro, S., \& Bitektine, A. (2015). Global sustainability pressures and strategic choice: The role of firms' structures and non-market capabilities in selection and implementation of sustainability initiatives. Journal of World Business, 50(2), 326-341. doi: 10.1016/j.jwb.2014.10.009

Rakesh, S., Narendra, K., \& Sandeep, P. (2017). Thought self-leadership strategies and sales performance: Integrating selling skills and adaptive selling behavior as missing links. Journal of Business \& Industrial Marketing . doi: 10.1108/JBIM-06-2016-0127

Raybould, M., \& Wilkins, H. (2006). Generic Skills for Hospitality Management: A Comparative Study of Management Expectations and Student Perceptions. Journal of Hospitality and Tourism Management, 13(2), 177-188. doi: 10.1375/jhtm.13.2.177

Reid, M., \& Brady, E. (2012). Improving firm performance through NPD: The role of market orientation, NPD orientation and the NPD process. Australasian Marketing Journal (AMJ), 20(4), 235-241. doi: 10.1016/j.ausmj.2012.05.011

Reydet, S., \& Carsana, L. (2017). The effect of digital design in retail banking on customers' commitment and loyalty: The mediating role of positive affect. Journal of Retailing and Consumer Services, 37, 132-138. doi: 10.1016/j.jretconser.2017.04.003

Sambasivan, M., Abdul, M., \& Yusop, Y. (2009). Impact of personal qualities and management skills of entrepreneurs on venture performance in Malaysia: Opportunity recognition skills as a mediating factor. Technovation, 29(11), 798-805. doi: 10.1016/j.technovation.2009.04.002

Samson, D., Gloet, M., \& Singh, P. (2017). SYSTEMATIC INNOVATION CAPABILITY: EVIDENCE FROM CASE STUDIES AND A LARGE SURVEY. International Journal of Innovation Management, 21(07), 1750058. doi: 10.1142/S136391961750058X

Santos, D. F. L., Basso, L. F. C., Kimura, H., \& Kayo, E. K. (2014). Innovation efforts and performances of Brazilian firms. Journal of Business Research, 67(4), 527-535. doi: 10.1016/j.jbusres.2013.11.009

Sedera, D., Lokuge, S., Grover, V., Sarker, S., \& Sarker, S. (2016). Innovating with enterprise systems and digital platforms: A contingent resource-based theory view. Information \& Management, 53(3), 366-379. doi: 10.1016/j.im.2016.01.001

Senichev, V. (2013). Human Resource Diversity and Performance within the Frame of Organizations, Teams and Individuals. Verslas: teorija ir praktika, 14(4), 337-345. doi: 10.3846/btp.2013.36

Silva, R., Gerwe, O., \& Becerra, M. (2017). Corporate brand and hotel performance: A resource-based perspective. Journal of Business Research, 79, 23-30. doi: 10.1016/j.jbusres.2017.05.019

Smith, C. G., \& Smith, J. B. (2019). Founders' uses of digital networks for resource acquisition: Extending network theory online. Journal of Business Research. doi: 10.1016/j.jbusres.2019.07.032

Stan De, S., Monique, R., \& Guy Van, G. (2017). Good employees through good jobs: A latent profile analysis of job types and employee outcomes in the Belgian electricity sector. Employee Relations, 39(4), 503-522. doi: 10.1108/ER-02-2016-0034 
ISSN 2582-2292

Vol. 3, No. 03 May-June; 2021

Stock, R. M. (2016). Understanding the relationship between frontline employee boreout and customer orientation. Journal of Business Research, 69(10), 4259-4268. doi: 10.1016/j.jbusres.2016.02.037

Stone, D. L., Deadrick, D. L., Lukaszewski, K. M., \& Johnson, R. (2015). The influence of technology on the future of human resource management. Human Resource Management Review, 25(2), 216-231. doi: 10.1016/j.hrmr.2015.01.002

Stundziene, A., Startiene, G., Remeikiene, R., \& Dapkus, M. (2015). Does the Survey Data on New Orders Lie? Procedia - Social and Behavioral Sciences, 213, 5-11. doi: 10.1016/j.sbspro.2015.11.395

Sugiyarti, G., Ferdinand, A. T., \& Nurchayati, T. (2018). Acculturative Products Uniqueness Antecedence for Successful Marketing Performance. DLSU Business \& Economics Review, $28(1), 11$.

Susilo, H. a. B. (2019). The Pusuit for Brand Usage Intent: Insight in Higher Education which Used the Compatible Computer. International Review of Management and Marketing, 9(5), 125132. doi: http://doi.org/10.32479/irmm.8628

Susilo, W. H. (2016). An Impact of Behavioral Segmentation to Increase Consumer Loyalty: Empirical Study in Higher Education of Postgraduate Institutions at Jakarta. Procedia - Social and Behavioral Sciences, 229, 183-195. doi: 10.1016/j.sbspro.2016.07.128

Susilo, W. H. (2020a). Business Research Methods: Market Based Managment Approach in Apllication (S. I. I. Group Ed. First Edition ed.). Bogor, INA: IN MEDIA.

Susilo, W. H. (2020b). The Business Research: The Competency \& Confident- Building Approach (imuruz Ed.). Mauritius: LAMBERT Academic Publishing.

Susilo, W. H. (2020c). The Business Research: The Competency\& Confident-Building Approach (W. H. Susilo Ed. 1 ed.). RIGA LATVIA: LAP LAMBERT Academic Publihing.

Tate, M., Bongiovanni, I., Kowalkiewicz, M., \& Townson, P. (2018). Managing the "Fuzzy front end" of open digital service innovation in the public sector: A methodology. International Journal of Information Management, 39, 186-198. doi: 10.1016/j.ijinfomgt.2017.11.008

Thomas, E. (2013). Supplier integration in new product development: Computer mediated communication, knowledge exchange and buyer performance. Industrial Marketing Management, 42(6), 890-899. doi: 10.1016/j.indmarman.2013.05.018

Tse, H. H. M., Huang, X., \& Lam, W. (2013). Why does transformational leadership matter for employee turnover? A multi-foci social exchange perspective. The Leadership Quarterly, 24(5), 763-776. doi: 10.1016/j.leaqua.2013.07.005

Vargo, S. L., Koskela-Huotari, K., Baron, S., Edvardsson, B., Reynoso, J., \& Colurcio, M. (2017). A systems perspective on markets - Toward a research agenda. Journal of Business Research, 79, 260-268. doi: 10.1016/j.jbusres.2017.03.011

Vargo, S. L., \& Lusch, R. F. (2017). Service-dominant logic 2025. International Journal of Research in Marketing, 34(1), 46-67. doi: 10.1016/j.ijresmar.2016.11.001 
Vargo, S. L., Maglio, P. P., \& Akaka, M. A. (2008). On value and value co-creation: A service systems and service logic perspective. European Management Journal, 26(3), 145-152. doi: 10.1016/j.emj.2008.04.003

Vargo, S. L., Wieland, H., \& Akaka, M. A. (2015). Innovation through institutionalization: A service ecosystems perspective. Industrial Marketing Management, 44, 63-72. doi: 10.1016/j.indmarman.2014.10.008

Vos, F. G. S., Schiele, H., \& Hüttinger, L. (2016). Supplier satisfaction: Explanation and out-ofsample prediction. Journal of Business Research, 69(10), 4613-4623. doi: 10.1016/j.jbusres.2016.04.013

Walmsley, B. (2016). From arts marketing to audience enrichment: How digital engagement can deepen and democratize artistic exchange with audiences. Poetics, 58, 66-78. doi: 10.1016/j.poetic.2016.07.001

Wang, C.-J., Tsai, H.-T., \& Tsai, M.-T. (2014). Linking transformational leadership and employee creativity in the hospitality industry: The influences of creative role identity, creative selfefficacy, and job complexity. Tourism Management, 40, 79-89. doi: 10.1016/j.tourman.2013.05.008

Wang, Z., Sharma, P. N., \& Cao, J. (2016). From knowledge sharing to firm performance: A predictive model comparison. Journal of Business Research, 69(10), 4650-4658. doi: 10.1016/j.jbusres.2016.03.055

Xerri, M. J., \& Reid, S. R. M. (2017). HUMAN RESOURCES AND INNOVATIVE BEHAVIOUR: IMPROVING NURSING PERFORMANCE. International Journal of Innovation Management, 1850019. doi: 10.1142/S1363919618500196

Xiaohong, Z., Chengfeng, L., Yanbo, W., \& Gaowen, T. (2015). The impact of employees' relationships on tacit knowledge sharing. Chinese Management Studies, 9(4), 611-625. doi: 10.1108/CMS-06-2015-0126

Xu, S., Wang, Y.-C., \& Wen, H. (2019). A case study for student leadership development: A goal setting perspective. Journal of Hospitality, Leisure, Sport \& Tourism Education, 24, 168-177. doi: 10.1016/j.jhlste.2019.03.001

Yulius, S. a. (2019). The Competitive Advantage: Insight from Private Universities. PEOPLE: International Journal of Social Science, 4(3), 1240-1252. doi: http://dx.doi.org/10.20319/pijss.2019.43.12401252

Zhao, G., Feng, T., \& Wang, D. (2015). Is more supply chain integration always beneficial to financial performance? Industrial Marketing Management, 45, 162-172. doi: 10.1016/j.indmarman.2015.02.015 